\title{
Mindanao, Konflik dan Terorisme: Kajian Pendahuluan atas Ketegangan dii Filipina Selatan
}

\author{
Al Chaidar, M. Akmal, Saifullah Ali, Nanda Amalia, Dara Quthni Effida \\ Peneliti senior dan dosen Fisip Universitas Ma-likussaleh, Aceh, Indonesia
}

\section{Abstract}

Mindanao is the second largest island in Philippines and one of the three main island groups along with Luzon and Visayas, the South Philippines. Mindanao is one of region in Southeast Asia which has been spectacularly a bright spot of world-class terrorism, because of the very high incidents of piracy and the ever-growing threat of terrorism. Southeast Asia is the region most vulnerable to piracy, accounting for about 50 percent of all attacks worldwide. This situation is exacerbated by the indigenous people of terrorist groups with strong maritime traditions. The nexus exchange between piracy and terrorism makes maritime terrorism in Southeast Asia a regional security concern. The Abu Sayyaf (ASG), Free Aceh Movement (Gerakan Aceh Merdeka, GAM), and Jemaah Islamiyah (JI) are the three terrorist groups in South Philippines, Southeast Asia with the intent and proven ability to engage in maritime terrorism. Of this group, the Abu Sayyaf is the best known but least understood and it has been source of tension in the South Philippines and Southeast Asia

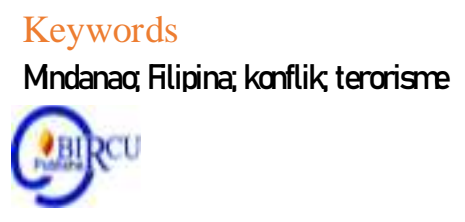

\section{Pendahuluan}

Mindanao adalah pulau terbesar kedua di Filipina dan salah satu dari tiga kelompok pulau utama bersama dengan Luzon dan Visayas. Berbeda dengan bagian utara Filipina yang secara kultural mewarisi budaya Barat (Spanyol dan Amerika) yang kental, maka wilayah selatan kontras terlihat sebagai warisan kultur Islam. Bangsa Filipina yang dikenal dengan sebutan Filipino, terdiri dari beberapa suku bangsa yang mendiami berbagai wilayah di Filipina. Mayoritas suku bangsa di Filipina adalah Tagalog, bersama suku-suku bangsa lainnya sebagai minoritas di negara ini. Mindanao, terletak di bagian selatan Filipina, adalah kawasan hunian bersejarah bagi mayoritas kaum Muslim atau suku Moro serta etnis lainnya seperti Maranao dan Tausug. Peperangan untuk meraih kemerdekaan telah ditempuh oleh berbagai faksi Muslim selama lima abad melawan para penguasa. Pasukan Spanyol, Amerika, Jepang dan Filipina belum berhasil meredam tekad mereka yang ingin memisahkan diri dari Filipina yang mayoritas penduduknya beragama Katolik. Kini mayoritas populasi Mindanao beragama Katolik berkat pola kepemilikan tanah yang tidak adil dan banyaknya pendatang ke wilayah ini. Hal ini memicu kemarahan kaum Muslim Mindanao yang miskin dan tersisih serta gerakan separatis yang telah berjuang selama ratusan tahun.

Dalam beberapa tahun terakhir, Mindanao menjadi wilayah yang diperhatikan dengan cermat seiring dengan munculnya organisasi teroris Islamis yang berkaitan erat dengan konflik di Timur Tengah. Mindanao diyakini menjadi basis kelompok teroris Abu Sayyaf dan Jemaah 
Islamiyah yang kemunculannya mengurangi peran kelompok pejuang kemerdekaan yang lebih moderat dan nationalistis seperti Front Pembebasan Islam Moro (MILF).

Konflik Moro adalah sebuah pemberontakan yang sedang berlangsung di pulau Mindanao, Filipina. Pada 1969, ketegangan politik dan pertempuran terbuka berkembang di antara Peme-rintah Filipina dan kelompok-kelompok pemberontak Muslim Moro. Pemberontakan Moro berujung pada pembantaian Jabi-dah, yang menewaskan 60 komandan Muslim Filipina atas operasi terencana untuk mengklaim kembali bagian timur negara bagian Malaysia Sabah. Sebagai tanggapannya, profesor Universitas Filipina Nur Misuari mendirikan Front Pembebasan Nasional Moro (MNLF, Moro National Liberation Front), sebuah kelompok pemberontak bersenjata yang berniat mendirikan Mindanao yang independen. Pada tahun-tahun berikutnya, MNLF terbagi dalam beberapa kelompok yang berbeda yang meliputi Front Pembebasan Islam Moro (MILF, Moro Islamic Liberation Front), yang ingin mendirikan sebuah negara Islam di Filipina.

Bangsamoro adalah etnoreligius Muslim yang terdiri atas 13 suku Austronesia yang mendiami Filipina bagian selatan. Front Pembebasan Islam Moro atau dalam bahasa Inggris disebut Moro Islamic Liberation Front (MILF), adalah kelompok militan Islam yang berpusat di selatan Filipina, didirikan sebagai bentuk perlawanan terhadap pemerintahan pusat Filipina yang dianggap diskriminatif terhadap komunitas Moro di Filipina selatan. Daerah tempat kelompok ini aktif dinamai Bangsamoro oleh MILF dan meliputi bagian selatan Mindanao, kepulauan Sulu, Palawan, Basilan,Tawi-Tawi dan beberapa pulau yang bersebelahan. Kota Jolo terletak di pulau Sulu. Kesultanan yang dulu berkuasa di daerah ini adalah Kesultanan Maguindanao dan Kesultanan Sulu. Kedua kesultanan itu beragama Muslim.

Pemberontakan Moro berakar dalam sejarah panjang pemberon-takan orang Bangsamoro melawan penguasa asing, bermula pada aneksasi Amerika atas Filipina pada 1899. Sejak itu, pemberontakan Moro beralih melawan pemerintah Filipina.

Jumlah korban konflik tersebut beragam; namun, perkiraan konservatif dari Program Data Konflik Uppsala mengindi-kasikan bahwa sekitar 6,015 orang tewas dalam konflik bersenjata antara Pemerintah Filipina dan faksi ASG, BIFM, MILF, dan MNLF antara 1989 dan 2012.

\section{Kajian Pustaka}

Konflik Moro di Filipina ini adalah sebuah konflik yang ber-kelanjutan dari masa penjajahan sampai masa kemerdekaan bahkan dikatakan masih berlanjut sampai abad 21 ini. Namun untuk pembahasan dalam konflik ini babakan waktu yang pakai sampai abad 20. Konflik Moro di Filipina bervariasi, bervariasia dalam hal ini berarti konflik ini bukan hanya tertuju dengan satu pihak saja, namun berbagai pihak. Dapat dikatakan konflik ini berawal masa penjajahan antara penjajahan Spanyol, Amerika, dan setelah merdeka bahkan dengan pemerintahan Filipina sendiri, setelah itu juga dengan para migran atau dengan kelom-pok Kristen di Filipina.

Berawal dari penjajahan Spanyol pada abad ke 17, Spanyol datang membawa kondisi sosial politik yang baru dengan kolonialnya. Spanyol menduduki Filipina Utara, dengan menye-barkan agama Kristen. Setelah menguasai Filipina Utara dengan daerah Luzon dan sekitarnya. Namun ketika Spanyol akan menguasai daerah Filipina Selatan yang mayoritas beragama Islam tidak berhasil ditaklukan. Perlawanan di Filipina Selatan dilakukan oleh Sultan Sulu, Manguindanao, dab Buayan yang oleh orang-orang Spanyol disebut sebagai orang Moro (karena kulitnya hitam seperti orang Islam di Afrika Utara) (Wiharyanto, 2011: 39). 
Menurut Spanyol Kesultanan Islam merupakan cerminan masyarakat yang terbelakang, bar bar, kasar dan tidak beradab. Selama bertahun-tahun Spanyol yang pada itu merupakn salah satu negara super power bersama Portugis tidak berhasil menguasai wilayah Mindanao. Upaya pemerintah Spanyol untuk menguasai mindanao dalam kurun waktu 200 tahun tidak berhasil menguasai wilayah Mindanao baik dalam konteks tujuan politik ekonomi maupuan penyebaran agama secara keseluruhan. Hanya beberapa wilayah saja di bagian utara kepulauan Mindanao yang berhasil kuasai yakni di Davao del Norte maupun Zamboanga del Norte. Berbagai perlawanan telah dilakukan oleh kelompok Moro, perang melawan Spanyol disebut Perang Moro (Surwandono 2013: 40-41).

Perang melawan Spanyol membuat hubungan antara Kasultan-an Sulu dan Maguindanao yang awalnya kurang harmonis menjadi sangat kuat dalam menghadapi pemerintahan Spanyol. Ketika tahun 1898 Amerika Serikat datang ke Filipina, karena orangorang Filipina Selatan tidak mau membantu pemimpin Filipina Utara dan Spanyol untuk mengahadapi Amerika, akhir-nya Filipina jatuh ketangan Amerika. Hal tersebut ditandai dengan Perjanjian Paris 10 desember 1898. Pada masa ini Fili-pina Selatan berhasil dikuasai oleh pihak Amerika karena ia berhasil membujuk para datu agar berpihak kepadanya. Berbeda dengan Spanyol, pemerintahan Amerika Serikat tidak menun-jukkan langsung "muka" penjajahnya tetapi lebih mengabur-kannya dengan misi yang lebih menekankan pendidikan dan pembangunan.

Kohesifnya koalisi antara kasultanan Sulu dan Maguindanano dalam mensikapi kemungkinan penetrasi Amerika Serikat di Mindanao membuat pemerintah Amerika Serikat lebih memilih mengelola dan menguasai di Mindanao melalui cara-cara buda-ya, sosial maupun ekonomi dalam bentuk kebijakan modernisasi Mindanao (Surwandono, 2013: 41). Modernisasi disini diartikan bahwa Amerika berusaha untuk meningkatkan taraf kehidupan Moro, namun ternyata tidak mendapatkan tanggapan positif. Untuk mengangkat desa-desa tertinggal yang dilakukan oleh orang-orang Filipina Utara terhadap orang-orang Filipina Selatan itupun dianggap sebagai tindakan yang agresi terhadap orang-orang Moro.

Di sisi lain Amerika juga tidak menganjurkan permusuhan Kristen-Islam, namun Amerika tetap menumbuhkan benih-benih permusuhan karena Amerika mendatangkan beribu-beribu penetap Kristen kedaerah-daerah Islam. Dalam kebijakan resmi yang ditempuh Amerika Serikat adalah membiarkan kehidupan agama orang-orang Moro serta kebiasaan ritualnya tidak ter-ganggu. Karena Filipina selatan menentang adanya modernisasi sehingga ketika diperkenalkan akan adanya pemerintahan modern yang bisa menerima hanyalah kelompok Filipina Utara. Di Filipina Selatan masih menggunakan sisitem tradisional yaitu datu, sikap Amerika ini memanjakan datu-datu yang mengakui kedaulatan Amerika dan menindas datu-datu yang keras kepala.

Dan akibatnya yang menduduki jabatan pemerintahan yaitu orang-orang Filipina Utara, sedangkan orang-orang Moro sema-kin tertinggal dalam pemerintaha, dan ketika merencanakan akan adanya kemerdekaan orang-orang Moro ini tidak diikut-sertakan. Ketika dikeluarkannya Undang-Undang Balcon Bill 1926 yang mana Amerika Serikat mendukung pilihan elite Filipina yang hendak mengggabungkan wilayah Kasultanan Islam di Mindanao kedalam wilayah Filipina. Hal tersebut membuat hubungan antara Kasultanan Islam dengan Amerika Serikat menjadi kurang baik. Dikeluarkannya hal tersebut membuat kesultanan Islam Mindanao mengajukan petisi kepada pihak Amerika Serikat agar tidak dimasukkan kedalam wilayah Filipina. Menurut Surwandono, (2013: 56) menyatakan bahwa:

"Langkah ini dilakukan dalam 3 tahap yakni petisi masyarakat Sulu, tertanggal 9 Juni 1921.kemudian dilanjutkan dengan petisi, yang sering dikenal dengan Zamboanga Declaration, tertanggal 1 Februari 1924, dan petisi yang terakhir diajukan kembai pada tanggal 18 Maret 1935, yang dikenal dengan Dansalam Decla-ration, dimana 120 datuk Moro 
terutama dari Lanano menge-luarkan "Deklarasi Dansalam" yang menyatakan pemisahan diri dari pemerintahan persemakmuran dan memilih berada dibawah protektorat Amerika Serikat sampai masyarakat Moro dapat membentuk pemerintahan sendiri ."

Meskipun terjadinya petisi-petisi tersebut pada PD II, Amerika Serikat mampu mengajak orang-orang Moro berjuang dengan orang-orang Filipina Utara. Mereka bersamasama melakukan perang gerilya melawan Jepang. Pada saat itu semua tidak memperdulikan latar belakang mereka masing-masing. Dengan dibungkus semangat patrotisme sehingga menimbulkan rasa nasionalisme yang kuat. Penjajahan Amerika Serikat atas Filipina ternyata tidak sesuai harapan Amerika, daerah jajahan itu tidak dianggap sebagai asset yang berarti dibidang ekonomi. Keun-tungan yang berhasil diperoleh dari investasi dijajahan Filipina sangat sedikit. Biaya pemerintahan tidak dapat sepenuhnya ditutupi dari pemasukkan pajak setempat, sementara biaya tersebut diperbesar oleh tambahan untuk biaya pertahanan militer. Singkatnya, Filipina secara ekonomis dapat dipandang sebagai merugikan bagi Amerika Serikat.

Filipina memperoleh kemerdekaan dari Amerika Serikat pada tahun 1946. Namun dengan adanya kemerdekaan Filipina tidak mengubah apapun dan tidak mempunyai arti bagi orang-orang Moro. Mereka tetap mengalami berbagai bentuk diskriminasi dan marjinalisasi seperti; kemiskinan, sulitnya memperoleh lapangan pekerjaan dan rendahnya tingkat pendidikan di wilayah Moro, bahkan tidak jarang diskriminasi telah mengarah kepada kekerasan militer.

Pemerintah tetap memasukkan wilayah Mindanao kedalam wilayah administratif Filipina dan tidak merespon dengan petisi-petisi yang diajukan oleh orang-orang Moro. Pemerintah Manuel Quezon tidak memerdulikan tuntutan orang-orang Moro di Mindanao, dan bahkan menempatkan Mindanao sebagai salah satu aset penting untuk menyelesaikan problem yang ada di Luzon dan Visayas seperti problem pertanahan dan investasi ekstratif maupun agraris. Kebijakan itu diambil karena Minda-nao merupakan wilayah yang mempunyai ketersediaan lahan sangat luas dan sumber daya alam untuk investasi yang besar.

Karena tidak adanya respons dari pemerintah yang membuat kekecewaan Datu Utdog Matalam mendirikan sebuah organisasi MIM (Moro Independent Movement) yang menginginkan Moro merdeka. Selain adanya MIM juga lahirnya MNLF (Moro National Liberation Front) organisasi yang dipimpin Nur Misuari ini sukses mendapatkan dukungan Dunia Internasional termasuk OKI. dan MILF (Moro Islamic Liberation Front).

Perkembangan kelompok-kelompok bersenjata Moro mening-katkan seranganya terhadap kesatuan-kesatuan militer di Fili-pina sehingga banyak tentara pemerintah yang menjadi korban. Sehingga banyak pasukan-pasukan dari pusat pemerintahan dikirim ke Filipina Selatan dalam jumlah besar. Pada bulan Oktober 1972 meletus pemberontakan yang lebih hebat. Tentara pemberontak mengambil alih pemancar radio pemerintah di Mindanao. Serangan tersebut dipersiapkan lebih rinci, terbukti sasarannya dipilih dengan baik dan waktu serangan juga ditetapkan melalui perencanaan yang matang.

Gerakan MNFL menyadari bahwa jika tidak ada bantuan dana dari pihak asing maka mereka tidak akan bisa bertahan melawan tentara pemerintah. Untuk menyerap dana asing dari luar, MNLF mendirikan perwakilan diberbagai negara Islam dan melakukan propaganda yang menunjukkan penindasan peme-rintah Filipina terhadap penduduk Moro (Wiharyanto, 2011 :47). Negara Libya yang merupakan negara pertama yang mem-berikan bantuan tidak terbatas. Dengan bantuan tidak terbatas ini penduduk Moro ini melengkapi dirinya dengan senjata-senjata yang mutakhir. Libya tidak hanya memberikan bantuan dana namun juga dengan senjata. Juga terjadi pengiriman kader-kader militan MNLF keluar negeri untuk menjalani latihan militer dengan bantuan dari elite Kasultanan Mindanao yang kecewa dengan kebijakan pemerintah Marcos. Gelombang pertama pengiriman pelatihan kombatan 
MNLF atau yang lebih dikenal sebagai Top 90 dan termasuk ketua MNLF Nur Misuari, di Pulau Pangkor dekat Pulau Pinang di Malaysia melalui fasilitas Libya (Surwandono, 2013: 59). Selain Libya dan Malaysia pada tahun 1980-an , bahwa Syiria melibatkan diri dalam pelatihan militan Moro.

Selain Moro yang meminta bantuan akan tetapi pihak dari pemerintah juga meminta bantuan kepada pihak asing untuk menghadapi pemberontak Moro. Pemerintah Filipina meminta bantuan senjata kepada Amerika Serikat, selain Amerika peme-rintah Filipina juga meminta bantuan ke negara-negara Eropa lainnya. Perlawanan pihak Moro ini semakin kuat dan gigih untuk melawan pemerintah Filipina, apalagi ditambah dengan pijakan serta bantuan yang dimiliki. Karena itu pada tahun 1973 perlawanan bersenjata semakin meningkat. Dan akhirnya Marcos menyadari bahwa perang yang dilakukan akan berjalan lama dan banyak menghabiskan biaya. Disamping itu banyak jumlah korban yang berjatuhan, menyadari hal seperti itu Marcos memilih alternatif politik untuk memecahkan masalah Moro.

Konflik ini terjadi oleh kelompok Moro dengan kelompok Non Moro di Mindanao. Konflik ini dimulai ketika kelompok Non Moro atau para migran mengambil alih tanah orang Moro di Mindanao. Pada tahun 1918, jumlah penduduk Moro di Mindanao mencapai 80\% penduduk Moro dan Non Moro di Mindanao $20 \%$. Masyarakat Moro menempatai 18 wilayah dari 20 wilayah di Mindanao. Dan pada tahun 1970 penduduk Moro di Mindanao tinggal 20\% dan menempati 13 wilayah di Mindanao, sedangkan penduduk Non Moro menjadi 80\% de-ngan menempati 18 wilayah (Surwandono, 2013: 45). Dari pernyataan tersebut dapat disimpulan bahwa pada tahun 1918 dan 1970 terdapat perubahan yang drastis yang terjadi pada jumlah penduduk Non Moro dan penduduk Moro di Mindanao. Dan yang menempati 18 wilayah pada tahun 1970 tersebut adalah penduduk Kristen Mindanao. Perubahan peta kepemi-likan tanah menyebabkan konstruksi pekerjaan masyarakat Mindanao, masyarakat Moro yang sebelumnya menjadi pemilik tanah, maka berubah menjadi buruh yang mengerjakan tanah dari masyarakat Kristen.

Konflik pertanahan ini kemudian berkembang menjadi konflik yang berwatak primordial. Kebijakan pemerintah yang memin-dahkan etnis Viyasa dan membentuk sebuah kekuatan sipil untuk mengambilalih tanah dan mempertahankan tanah yang diambil. Pengambilan tanah yang digunakan sering meng-gunakan kekerasan bahkan sampai pada pembunuhan. Karena adanya kekuatan sipil tersebut sehingga mengakibatkan ber-bagai tragedi di awal dekade 1970-an dimana 40.000 penduduk Moro dibunuh oleh kelompok sipil bersenjata. Kelompok terse-but dinamakan dengan kelompok Ilaga, yang melakukan pembantaian kepada komunitas muslim. Sedangkan pemerintah Maros cenderung membiarkannya, sehingga yang awalnya kon-flik pertanahan berubah menjadi konflik agama di Mindanao.

Dari pihak Mindanao juga tidak berdiam diri, dikalangan elite bangsa Moro dengan kelompok sipilnya yang bernama Baracuda melakukan perlawanan kepada kelompok Ilaga maupun pemerintah pusat. Kelompok Baracuda menggunakan agama untuk memacu semangat Bangsa Moro agar tetap gigih untuk mempertahankan tanah dan harga dirinya. Kelompok ini juga menginternasionalisasikan konflik ini kedunia Islam agar komunitas Islam diseluruh dunia memberikan bantuan kepada Islam di Mindanao berdasar nama agama. Konflik yang berlarut-larut di Mindanao Filipina selatan bukan tanpa adanyanya usaha dari berbagai pihak untuk mengakhiri konflik ini. Baik yang dipelopori dari dalam maupun campurtangan pihak asing. Berikut beberapa usaha penyelesaian yang pernah dilaksanakan: Upaya peneyelesaian konflik ini diprakarsai oleh OKI pada tahun 1973 dengan membentuk komisi 4 negara. Ke 4 anggota-nya adalah Libia, Arab Saudi, Senegal dan Somalia untuk menyelidiki kasus kasus kekerasan yang dilakukan pemerintah Filipina terhadap Moro.namun bertambah menjadi 6 negara setelah Indonesia dan Bangladesh sebagai anggotanya. 
Hasil dari Tripoli Agreement adalah diakuinya secarah sah wilayah otonomi Mindanao yang meliputi 13 daerah seperti daerah Basilan, Sulu, Tawi-Tawi, Zamboangan del zur, Zamboangan del Norte, Lanao del Sur, Davao del Sur, South Cota-bato, Palawan, serta semua kota dan desa diwilayah tersebut. Dalam perjanjian ini juga mengatur kawasan Otonom untuk mendirikan pengadilan syari'ah, sekolah, system administrasi, sistem ekonomi dan keuangan, keamanan kawasan, badan perwakilan dan dewan eksekutif. Hal-hal mengenai kebijakan politik Luar Negeri dan Pertahanan nasional tetap menjadi tanggung jawab pemerintahan Pusat. Dan membuat wadah yang mernaman pemerintahan otonomi Moro (ARMM)

Menjelang tahun 90-an kekuasan pemerintahan pusat Filipina terganggu, hal ini membuat faksi-faksi muslim Moro kembali melakukan mobilisasi kekuatan untuk memanfaatkan moment tersebut untuk mendeklarasikan pembentukan Negara Moro Merdeka. MNLF yang selama menjalankan Tripoli Agreement merasa dikapitulasi oleh kebijakan marcos memilih untuk me-lanjutkan perjuangan bersenjata untuk pembentukan negara yang merdeka.

Dalam menghadapi mobilisasi di Minandao presidan Aquino meminta negosiasi dilakukan lagi, akhirnya disetujui oleh Nur Misuari pemimpin MNLF. Akhirnya 3 orang dikirim ke Jeddah, Arab Saudi guna bernegosiasiNegosiasi dalam Jeddah Accord 1987. Aquino bersedia berunding masalah ekonomi, politik, social dan budaya kecuali perbincangan tentang isu Moro Mer-deka. Hasil dari negosiasi antara MNLF dan Pemerintah Filipina adalah peningkatan status dari sebelumnya wilayah otonom menjadi wilayah Otonomi diperluas.

Proses perdamaian di Mindanao selatan terus berlangsung setelah bergantinya rezim Presiden Aquino dengan Fidel Ramos yang lebih proaktif. Seiring berjalannya waktu kelompok kelom-pok militan seperti Abbu Sayyaf terus melakukan terror dan seranganserangan di Mindanao, termasuk melakukan pencu-likan dengan tebusan. Meskipun kekerasan terus berlangsung Presiden Ramos tetap akan melanjutkan usaha perdamaian di Mindanao selatan.

\section{Pembahasan}

\section{Range Negosiasi dalam Final Peace Agreement 1966}

Pada tanggal 2 September 1996, Final Peace Agreement disepa-kati secara formal dengan disaksikan oleh menteri luar negeri Indonesia, Ali Alatas dan Sekjen OKI di Jakarta. Dengan meng-hasilkan 81 Point kesepakatan yang intinya adalah mening-katkan status wilayah otonomi diperluas menjadi ekonomi khu-sus. Melaksanakan pemilihan umum untuk daerah Minda-nao dan dimenangkan oleh Nur Misuari dengan 90\% suara. (Surwandono, 2013:127-147).

Konflik dan Kemiskinan 2 hal yang tidak pernah bisa kita pisahkan. Konflik yang berlarut-larut menimbulkan berbagai dampak baik dalam hal ekonomi dan pendidikan. Konflik yang terjadi menciptakan suatu kondisi dimana tingkat keamanan sangat rendah, hal ini memengaruhi sistim ekonomi Moro yang mengalami gangguan khususnya dalam Hal Investasi yang rendah. Banyak anak-anak moro yang tidak bias bersekolah akibat sekolahnya digunakan sebagai temppat pengungsian. Infrastruktur rusak dan rumah-rumah harus ditinggalkan akibat konflikini. Biaya pembangunan kembali Minandao paska konflik membutuhkan jumlah biaya pembangunan yang tidak sedikit. 
Table1. Serangan Pembajak Menurut Wilayah, 1999-2001

\begin{tabular}{crrrrrr}
\hline Tahun & \multicolumn{2}{c}{ Perairan } & \multicolumn{2}{c}{ Perairan Teritorial } & \multicolumn{2}{l}{ Pelabuhan } \\
\hline 2003 & 102 & $24 \%$ & 88 & $21 \%$ & 232 & $55 \%$ \\
2002 & 49 & $13 \%$ & 72 & $19 \%$ & 262 & $68 \%$ \\
2001 & 79 & $21 \%$ & 125 & $34 \%$ & 166 & $45 \%$ \\
2000 & 136 & $29 \%$ & 224 & $48 \%$ & 111 & $23 \%$ \\
1999 & 38 & $12 \%$ & 201 & $68 \%$ & 70 & $23 \%$ \\
\hline
\end{tabular}

Sumber: Derek Johnson dan Mark Valencia, Piracy in Southeast Asia: Status, Issues, and Responses (Singapore: ISEAS, 2005).

Konflik Moro di Minandao Filipina selatan merupakan konflik berkepanjangan yang belum terselesaikan. Usaha-usaha yang dilakukan untuk proses perdamaian terus dilakukan beriringan dengan usaha-usaha kemerdekaan yang terus dikumandangkan oleh para kelompok separatis-separatis moro untuk membentuk sebuah Negara sendiri yang merdeka dan bebas dari Intervensi pemerintahan Filipina. Isu-isu agama yang diawa dalam konflik ini membuat konflik ini semakin memanas. Konflik ini akan terus berlanjut apabila kamu minoritas muslim difilipina terus mendapat tekanan-tekanan politik dari pemerintahan pusat. Yang mereka tuntut hanyalah merdeka.

Di Filipina, konflik bermula berkaitan erat dengan persaingan misi agama Islam dan Kristen pasca abad ke-13. Diskriminasi negara terhadap kelompok minoritas Muslim menjadi lebih kentara ketika menyebut mereka sebagai Moro, artinya identik dengan kelompok Islam yang dulu menduduki Spanyol. Dari sinilah konflik terus berkecamuk. Agama dan identitas etnik bahkan menempati bagian penting dari konflik itu.

Pemberontakan oleh kelompok Muslim Minoritas di Mindanao, Filipina Selatan, misalnya, lebih karena diperlakukan tidak adil dalam kehidupan ekonomi dan politik, walaupun ada unsur 'agama' yang bermain disini. Filipina Selatan adalah sebuah daerah yang tidak hentihentinya mengalami konflik. Daerah ini adalah daerah dimana mayoritas penduduknya beragama Islam. Konflik yang terjadi di daerah ini adalah karena adanya persaingan antar agama diluar faktor lain seperti politik, social dan budaya. Hal yang paling krusial adalah yang menyangkut dengan agama.

Konflik di Filipina dimulai dengan kolonisasi yang dilakukan oleh orang arab dan kemudian oleh Kristen, yang mana keberbedaan kedua agama tersebut, hingga sekarang masih berkom-petisi untuk memperebutkan perhatian penduduk pribumi. Orang-orang Arab Islam bergeser ke Selatan Filipina ketika orangorang Kristen menduduki Utara Filipina. Menurut orang-orang Islam akar dari gerakan separatis di Filipina "didalamnya adanya kultur dan agama yang jauh berbeda antara Kristen, Daerah Utara di Jajah, dan Muslim, beranggapan Selatan bukanlah taklukan dari Kristen. Ini berarti daerah Selatan yang pada awalnya didominasi oleh Muslim telah terusik dengan kehadiran agama Kristen sampai ke daerah ini.

Konflik yang terjadi di Filipina mulai terjadi sejak kedatangan orang-orang Kristen Spanyol dan berhasil menduduki daerah Filipina Utara atau kepulauan Luzon pada tahun 1565. Sejak saat itu orang-orang Spanyol yang ingin mendirikan Filipina sebagai daerah koloni dan memasukan penduduk ke dalam agama Kristen. Sejak saat itu terjadi perlawanan perlawanan antara orang Spanyol dan penduduk pribumi Islam, dan dimenangkan oleh Spanyol pada tahun 1673.

Konflik di Filipina terus berlanjut, setelah Spanyol berkuasa maka beralih kekuasaan kepada Amerika, Jepang dan sampai Filipina memproklamasikan dirinya sebagai Negara 
yang merdeka pada tanggal 4 Juli 1946. Pada masa pemerintahan Marcus, konflik awal terjadi akibat suatu peristiwa pembunuhan di Corregidor. Para sukarelawan Muslim Filipina, yang dilatih dalam taktik geriliya oleh suatu pasukan resmi, dibunuh atas perintah komandan pasukan. Mereka menolak di kirim ke Sabah guna melakukan infiltrasi Militer.

Karena peristiwa ini terbentuklah Front Pembebasan Muslim Moro (MNLF), MNLF adalah sebuah gerakan yang sangat berpengaruh dalam memperjangkan kebebasan Muslim Moro. Dua kelompok lainnya adalah seperti Front Pembebasan Islam

Moro (MILF) dan yang paling belakangan adalah Abu Sayyaf yang terbentuk pada tahun 1989. Ketiga kelompok gerakan ini memiliki tujuan yang sama yakni ingin mendirikan sebuah Negara teokrasi Islam di Mindanao Filipina Selatan dan pemba-ngunan ekonomi di wilayah mereka.

Dalam tulisan ini akan membahas mengenai gerakan Kelompok Abu Sayyaf, dimana gerakan ini telah memperlihatkan sebuah keresahan di Filipina Selatan karena aksi-aksi mereka yang telah menjurus kepada tindak terorisme.

Filipina merupakan bagian dari Asia Tenggara. Negeri ini memi-liki sekitar 7000 pulau besar dan kecil. Luasnya sekitar 300.000 km2. Kawasan ini ditemukan oleh Ferdinand Magellans, seorang pengembara Bangsa Spanyol. Baru 42 tahun kemudian daerah ini dijadikan koloni Spanyol. Sejak Amerika Serikat memer-dekakan negeri ini, bentuk pemerintahannya adalah republik dengan ibukotanya Manila City. Menurut sensus tahun 2005, jumlah penduduknya 97.857.473 jiwa. Mayoritas pendu-duknya beragama Roma Katholik. Sekitar 5\% (4.392.872 jiwa) penduduk-nya beragama Islam. Jumlah inilah yang disebut Muslims Philippinos, atau disebut juga Bangsa Moro. Wilayah Bangsa Moro meliputi Mindanao, Sulu, Tawi-tawi dan Palawan. Inilah yang sering disebut sebagai Filipina Selatan. Daerah ini meliputi 23 Provinsi dengan luas daerah $96.438 \mathrm{Km} 2$ (kira-kira 33\% dari total keseluruhan Filipina).

Bangsa Moro terdiri dari 13 etnis suku, yaitu Maranao, Maguin-danao, Tausuq (Sulu, Suluk, Zolo), Samal, Yakan, Sangil, Bajao, Kalibogan, Jama Mapun, Iranun, Palawanon, Kalagan dan Molbog. Sementara itu suku Tausuq merupakan gabungan dari beberapa suku, yaitu suku, Buranun, Taguimaha, Baklaya, Dampuan dan Banjar. Suku Baklaya dipercaya sebagai suku pendatang dari Sulawesi, Indonesia. Mungkin saja ia adalah suku Bugis dari Sulawesi Selatan. Suku Banjar berasal dari Borneo (Kalimantan), Indonesia. Sedangkan suku Dampuan dipercaya berasal dari Champa (Indochina) yang migrasi ke Filipina dan seluruh Asia Tenggara.

Bangsa Moro atau Bangsamoro, dalam penulisan kaum Minda-nao di Filipina Selatan, adalah nama bagi sebuah nation (bangsa) yang terdiri dari berbagai suku dan klan yang hidup di Minda-nao, Sulu, Tawi-Tawi dan Basilan. Filipina Selatan disebutkan sebagai tempat tinggal (hunian) tradisional Bangsa Moro. Huni-an tradisional ini dimaksudkan adalah bentuk tatanan sosial yang masih asli, belum bercampur dengan budaya asing. Bahkan belum bercampur dengan kebudayaan Islam. Daerah hunian tersebut meliputi Mindanao, Tawi-tawi, Sanga-sanga, Bato-bato, Zamboanga, hunian yang berbatasan dengan Brunei, Malaysia Timur, Kalimantan (Timur) dan Indonesia bagian timur.

Pada tataran tatanan sosial terkecil, dikenal istilah Barangay. Ia merupakan tatanan sosial terkecil, budaya tersendiri dengan wilayah hukum yang khas untuk sekitar $100 \mathrm{KK}$ yang dikepalai oleh seorang Datu (Datuk). Mungkin sekarang bisa dipadankan dengan ketua kampung. Tata cara hidup mereka ini disebut Luwaran. Pada tingkat wilayah yang lebih besar lagi, ada wilayah-wilayah dikuasai oleh kepala suku berupa raja-raja kecil yang tinggal dekat dengan keramaian, misalnya pelabuhan. Mereka percaya kepada kekuatan alam. Kepercayaan animisme menjadi anutan penduduk. Ketika pengaruh Hindu masuk berupa kedatangan pedagang India, mereka percaya kepada Dewa utama, yaitu Dewa Bathala (Batara). 
Kepercayaan penduduknya menjadi beragam setelah budaya mereka bersentuhan dengan budaya (lewat pedagang) Cina, Persia dan Arab (Islam).

Islam masuk ke Filipina, secara garis besar, Islam masuk ke Filipina dimulai dari abad 11-14 M. Abad 14-15, Islam ada dalam bentuk kekuasaan, yaitu pemerintahan kesultanan. Teori Islam masuk ke Filipina Selatan disebutkan dengan berbagai versi. Ada lewat pedagang. Ada lewat pengembara yang berlaku sebagai pedagang. Beberapa nama disebutkan, antara lain Mashaika, tiba di pulau Sulu. Diperkirakan berasal dari bangsa Melayu. Inilah orang pertama yang membawa dan menyebarkan Islam di Filipina. Ada nama Muhammad Kabungsuwan, datang ke suku Manguindanao di daerah Tinundan. Ada nama Sharif Awliya yang datang ke Mindanao. Ia berasal dari Johor. Penye-baran Islam di Mindanao dilanjutkan oleh menantunya yang bernama Sharif Maraja. Olehnya, Islam menyebar ke wilayah Davao, Danau Lanao dan Bukidnon. Ada pula nama Karim Al Makhdum, ulama sufi yang ahlu fikih, datang ke Sulu. Hanya cerita ulama ini bercampur legenda yang aneh-aneh. Ada pula nama Sharif Abubakar, asal dari Yaman Selatan (Hadralmauth), meneruskan kekuasaan Kesultanan Sulu, yang merupakan kekuatan Islam pertama di Filipina. Ia terlebih dahulu mendarat di Palembang dan Brunei. Kemudian ia menikahi putri raja Bwansa, raja Sulu waktu itu yang sudah beragama Islam. Ia menggantikan kedudukan mertuanya, menjadi raja. Dari eranya, hukum Islam diberlakukan, tetapi dengan tetap memperhatikan adat istiadat setempat yang tidak bertentangan dengan Islam. Dari kesultanan inilah akhirnya Islam menyebar ke seluruh Filipina.

Kekuatan Islam waktu itu dipegang oleh tiga kesultanan, yaitu kesultanan Sulu, Maguindanao dan Buayan. Tetapi kemudian Kesultanan Maguindanao dan Buayan dipersatukan oleh Sultan Kudarat menjadi kesultanan Maguindanao. Muslim Filipina adalah beraliran Sunni. Awal tahun 1970-an, banyak tokoh Islam dunia yang berkunjung ke Filipina. Mulai banyak pula pendu-duk asli Filipina yang belajar ke pusat-pusat kebudayaan Islam. Sepulang dari sana mereka menyebarkan Islam, mendirikan sekolah Islam, masjid, tempattempat mengajarkan dasar-dasar Islam dan Al-Quraan. Sampai sekarang terkenal lembaga pendidikan yang bagus mutunya bernama Jamiatul Al Islamiyah Filipina yang ada di kota Marawi.

Berbagai Konflik yang Terjadi. Penyebaran Islam lebih gencar lagi terutama oleh suku Sulu ketika Portugis bisa menguasai Malaka pada tahun 1511, sebuah bandar yang ramai dengan aktifitas perdagangan. Mereka membentuk kelompok-kelompok kecil dari berbagai barangay, berpencar ke Kalimantan, Minda-nao di wilayah utara dan ke suku Buranun di daerah pedalaman. Dari sinilah terjalin hubungan yang semakin erat dengan kesultanan Islam lainnya di Nusantara dan Malaya. Hubungan ini dijalin mengingat bahwa kedatangan Portugis dan bangsa barat lainnya tidak sekedar berdagang dan mencari komoditi perdagangan, tetapi mereka juga ingin menguasai wilayah dan menyebarkan agama.

Abad pertengahan 16, Islam mulai mengakar di Filipina. Bahkan sudah sampai ke pulau Luzon. Di Manila sendiri sudah berdiri kerajaan Islam kecil yang berada di Tondo. Abad 15-16 M, Islam diperkenalkan lewat jalur resmi kerajaan. Adalah raja Baguinda yang pertama sekali membolehkan negerinya mendapatkan dakwah Islam. Kedatangan Portugis ke Asia Tenggara adalah awal konflik yang terjadi antara penduduk asli Filipina, khusus-nya Muslim Moro, apalagi setelah mereka mampu menaklukkan Malaka. Bangsa kulit putih pertama yang masuk ke Filipina adalah Ferdinand Magellans tahun 1512. Ia bangsa Spanyol. Ia terbunuh oleh suku setempat dalam salah satu pertempuran.

Ada tiga suku besar bangsa Moro yang Muslim, yaitu suku Sulu (Tausuq), Maranao dan Maguindanao. Ada satu suku lagi, yaitu suku Banguingui yang merupakan suku Muslim terkecil jumlah-nya. Tetapi tiga suku pertama di atas merupakan grup Muslim yang acap dimanfaatkan Portugis untuk mencapai tujuannya. Datu Uttu dari suku Tausuq menyediakan 
perahu bagi penjajah Portugis untuk menghancurkan kelompok Islam suku Tausuq lainnya. Begitu pula ketika Marcos berkuasa, diktator ini berusaha terus meneruskan berusaha mematahkan perlawanan suku Tausuq.

Pada masa penjajahan Amerika Serikat, beberapa kelompok Muslim ikut menandatangani perjanjian damai, sementara yang lainnya terus berjuang. Perlawanan sengit yang dilakukan Datu Ali (tahun 1903) yang terkenal bertempur gagah berani, tetapi dipatahkan, dihancurkan bahkan beliau terbunuh akibat pengkhianatan Datu Plang. Kedatangan bangsa Barat lainnya adalah Spanyol. Mereka melancarkan peperangan dengan Bangsa Moro. Pada masa inilah terlihat perpecahan di kalangan para datu, berebut kekuasaan dan pengaruh. Terjadilah saling hasut yang menyebabkan terjadi perang antarsuku. Keadaan ini menguntungkan bangsa penjajah dan keadaan itu dimanfaatkan sebaik-baiknya untuk menaklukkan Bangsa Moro. Perjalanan panjang mereka dari Spanyol menuju Asia Tenggara memang direstui oleh Philip II, raja Spanyol waktu itu. "Kuberikan izin bagi kalian untuk menjadikan Bangsa Moro yang Muslim menjadi budak untuk kalian. Tetapi kularang kalian menjadikan budak bagi penduduk lain selain Bangsa Moro Muslim", begitulah isi surat raja Spanyol kepada Conquistador Miguel Lopez Legaspi yang bertindak sebagai kepala pasukan yang mendarat di pulau Cebu (tahun 1565). Dipimpin olehnya, dakwah Islam dihentikan dengan peperangan selama 300 tahun.

Dendam Spanyol terhadap Islam memang mengakar dalam sejarah. Islam menguasai mereka selama 4 abad. Karena itu kebencian mereka terhadap Islam dilampiaskan kepada Bangsa Moro. Berbagai pembantaian, pembunuhan dan pelecehan dilakukan oleh bangsa Spanyol ini. "Doktrin ajaran Islam adalah palsu, tidak benar dan merupakan hukum setan," melekat erat di kepala penjajah ini. Itu pula yang disebutkan Gubernur Spanyol dan kaki tangannya. "Islam adalah seperti api yang menyebar seperti wabah," kata uskup Salazar. Atau "Kaum Muslimin adalah perampok, lanun di lautan," kata Pio Pie, seorang pendeta Jesuit.

Bangsa Spanyol hanya mampu menaklukkan Bangsa Moro dengan kekuatan senjata, tetapi tidak dalam urusan keyakinan. Ketika kapal uap dipakai oleh kapal-kapal mereka tahun 1800-an, bangsa Moro tidak berdaya melawan bangsa penjajah ini. Para datu dan raja kecil terpaksa membayar upeti kalau tidak ingin kapal mereka dihancurkan, atau dirusak barang dagangan mereka, atau kampung-kampung dibakar. Bahkan Francisco Ducos, seorang pendeta bangsa Spanyol, memimpin sendiri pasukannya selama 7 tahun untuk melawan kaum Muslimin.

Menjelang abad $19 \mathrm{M}$, bangsa-bangsa penjajah lain (Inggris, Perancis, Belanda) mulai berdatangan ke Asia Tenggara. Hal ini mulai mengkhawatirkan Spanyol. Mulailah dilakukan penak-lukan besar-besaran terhadap Bangsa Moro, terutama terhadap suku Tausuq yang memang ahli berperang di laut. Adalah panglima perang Spanyol, Jendral Arolas, mengangkat dirinya sebagai sultan Sulu, di tengah perlawanan yang terus dilakukan oleh suku Tausuq (Sulu). Perlawanan yang Tiada Henti dari Bangsamoro dikenal dengan juramentado. Amerika Serikat datang ke`Filipina. Terjadilah perang antara dua bangsa penjajah ini, Amerika Serikat versus Spanyol. Spanyol keok dan tahun 1899 terpaksa angkat kaki dari Filipina. Bergantilah bangsa penjajah. Bukan berarti kondisi Muslim Moro menjadi baik dengan bergantinya penjajah. Berbagai pembantaian, penindas-an, intimidasi, pelecehan, dan kesukaran hidup lainnya, terjadi selama Filipina dijajah Amerika Serikat.

Tahun 1946, Filipina dimerdekakan AS. Namun, minoritas Muslim Moro, suatu sebutan untuk penduduk migran, atau penduduk dengan kuantitas kecil dan spesifik, atau entitas penduduk yang dipaksa bergabung dengan kelompok besar, tetap saja tidak seketika merdeka. Mereka harus terus berjuang untuk memunculkan identitas dirinya. Namun kemerdekaan yang diraih Filipina mempunyai nilai tambah plus minusnya. Pertengahan abad 20, hubungan Muslim dengan dunia Islam, dilakukan melalui masyarakat Muslim Asia 
Tenggara, semisal Malaysia-Riau Indonesia (puak Melayu), Thailand (Pattani), dan atau Brunei Darussalam. Tetapi setelah terlepas dari AS, hubungan Muslim Moro dapat langsung terjalin ke pusat Islam di Timur Tengah. Apalagi setelah pulau Mindanao dan Sulu menjadi bagian dari Republik Filipina. Pengaruh aliran reformis Mesir dan Pakistan mulai masuk ke Filipina. Nama-nama Muhammad Abduh, Jamaluddin Al Afghani, Sayyid Quthub, Abul A'la Maududi, dan pemikir lainnya.

Selamat Hashim, pendiri MILF (Moro Islamic Liberation Front) yang ikut terpengaruh terhadap gerakan reformis Sayyid Quthub dan Abul A'la Maududi. Pada awalnya MILF berusaha mengubah nasib Muslim Moro dengan cara-cara damai.i Tetapi akhirnya perlawanan bersenjata terpaksa dilakukan. Muncullah MNLF (Moro National Liberation Front) yang memperjuangkan perlawanan bersenjata. Hubungan terjalin itu sangat menguntungkan Muslim Moro. Tahun 1970-an, ketika terjadi pembantaian yang dilakukan pemerintah Manila, Libya langsung be-reaksi dan membawa permasalahan Muslim Filipina ke forum OKI (Organisasi Konferensi Islam).

Perlawanan MNLF mereda setelah Manila tahun 1975 berusaha menegosiasikan tuntutan MNLF. Setahun kemudian dicapai kata sepakat, dikenal dengan Kesepakatan Tripoli, mengikat MNLF untuk menerima hak otonomi terbatas. Manila hanya mem-berikan otonomi di bidang pendidikan dan pengadilan, tidak di bidang pertahanan dan keamanan (militer) dan politik luar negeri yang masih dipegang oleh pemerintah Manila. Otonomi itu diberikan kepada 13 propinsi, yaitu Basilan, Sulu, Tawi Tawi, Zamboanga del Sur dan Del Norte, Cotabato Utara-Selatan, Maguindanao, Otoritas Sultan Kudarat, Lanao del Sur dan Lanao del Norte, serta Palawan.

Selain perlawanan bersenjata, Muslim Moro juga berjuang dengan cara damai di bawah pengawasan PBB. Perjuangan secara damai ini sangat unik. Pada tahun 1999, untuk pertama kalinya diadakan Moro People's Consultative Assembly, yang dilakukan dengan cara rapat raksasa, dihadiri lebih satu juta Muslim Moro. Pertemuan itu menghasilkan kesepakatan mendi-rikan pemerintahan Bangsa Moro yang mandiri. Rapat raksasa ini dilakukan berkalikali, antara tahun 1999-2001. Itu terjadi di Cotabato City dan Davao City (23 Oktober 1999), Marawi City (24 Oktober 1999), dan di Basilan (7 Desember 1999). Juga terjadi rapat raksasa lainnya tahun 2001 yang dihadiri 2,5 juta orang. Pada intinya, rapat-rapat massa yang besar itu menginginkan pemerintahan sendiri, sembari menolak otonomi terbatas dari hasil Kesepakatan Tripoli. Ferdinand Marcos pernah berusaha mencederai Kesepakan Tripoli itu secara halus, yakni berusaha memindahkan penduduk beragama Kristen ke 13 provinsi tersebut. Setelah cukup banyak penduduk beragama Kristen di 13 provinsi Muslim Moro itu, diadakanlah referendum untuk memberikan hak otonomi khusus.

\section{Kesimpulan}

Hipotesa yang didasarkan pada kajian awal BPPK mengemu-kakan beberapa pokok, sebagai berikut: (1) Kawasan Mindanao, terutama kepulauan di Laut Sulu, memiliki angka kemiskinan yang sangat tinggi hingga lebih dari 50\% (data 2015). (2) Faksi-faksi Abu Sayyaf survive karena adanya dukungan dari kelompok-kelompok masyarakat lokal, dimana dukungan tersebut berhasil dipertahankan oleh kelompok Abu Sayyaf, karena mereka memberikan limpahan (trickle down) perekono-mian yang berasal dari ransom penculikan tersebut. Dengan demikian, ada simbiosis mutualistik antara faksi-faksi Abu Sayyaf dan kelompok masyarakat dan elite setempat yang diuntungkan, yang juga berfungsi sebagai basis dukungan dan perlindungan kelompok tersebut. (3) Dengan demikian perlu dilakukan suatu kajian untuk bisa memahami secara tepat kondisi sosial politik dan ekonomi di kawasan Mindanao, dalam merumuskan suatu rekomendasi strategis untuk membawa penyelesaian 
yang bermartabat terhadap masalah keamanan di perairan Laut Sulu dan Laut Sulawesi tersebut. (4) Sejauh ini telah ada upaya bersama antara otoritas Indonesia, Malaysia dan Filipina, khususnya dari aspek kerja sama keamanan untuk mengatasi ancaman pelayaran di Laut Sulu. Namun, masih perlu diupayakan suatu terobosan baru yang akan memperkuat dampak dari kerja sama trilateral tersebut.

\section{Daftar Pustaka}

Abuza, Zachary, "Counter-Terrorism: The Return ofthe Abu Sayyaf," Strategic Studies Institute, 2014.

Abuza, Zachary. 2002. Tentacles of Terror:Al-Qaeda's Southeast Asia Linkages.Honolulu. Asia Pasific Center foSecurity StudiesAlagappa, Muthiah. 1986. US-ASEANSecurity Co-operation Limits and

Abdullah Taufik, Sharon Siddique, Tradisi dan Kebangkitan Islam di Asia Tenggara. Jakarta: LP3ES, 1989

Abdullah, Intuas. "Dispute Settlement Among Maranao: Case Studies of Conflict Resolution in Marawi City." Masters Thesis. Department of Anthropology. University of the Philippines, Diliman, Quezon City, 1982.

Abdullah, Taufik, (Editor) Ensiklopedi Tematis Dunia Islam Asia Tenggara, Jakarta: Ichtiar Baru Van Hoeve, 2002.

Banlaoi, Rommel C. "Maritime Piracy in Southeast Asia: current situation, countermeasures, achievements and recurring challenges." Conference on Global Challenge, Regional Responses: Forging a Common Approach to Maritime Piracy. 2011.

Banlaoi, Rommel C. "Maritime Terrorism in Southeast Asia: The Abu Sayyaf Threat." Naval War College Review 58.4 (2005): 63-82.

McKenna, Thomas M. The Philippines," South-South Network forNon-State Armed Group Engagement and the Institute for Political Violence and TerrorismeResearch, 2008.

Philstar News Online, "Abu Sayyaf abducts schoolprincipal in Sumisip," http://www.philstar.page.asp?id=826, diakses pada 14 April 2014. 